\title{
PELATIHAN PENDAMPING SOSIAL DALAM MENINGKATKAN KEMAMPUAN FASILITASI PROGRAM KELOMPOK USAHA BERSAMA
}

(Studi Des kripsi Pelatihan Pendamping Sosial KUBE Di Balai Bes ar Pendidikan Dan Pelatihan Kesejahteraan Sosial (BBPPKS) Regional II Bandung)

\author{
1)Siti Nurhasanah \\ Departemen Pendidikan Luar Sekolah Fakultas Ilmu Pendidikan \\ Universitas Pendidikan Indonesia Jl. Dr. Setiabudhi No. 229 Bandung \\ Email: anahbembem2@gmail.com \\ 2)Mus tofa Kamil \\ Departemen Pendidikan Luar Sekolah Fakultas Ilmu Pendidikan \\ Universitas Pendidikan Indonesia Jl. Dr. Setiabudhi No. 229 Bandung \\ Email:mustofakamil@gmail.com \\ ${ }^{3)}$ Asep Saepudin \\ Departemen Pendidikan Luar Sekolah Fakultas Ilmu Pendidikan \\ Universitas Pendidikan Indonesia Jl. Dr. Setiabudhi No. 229 Bandung \\ Email: asepsaefudin@gmail.com
}

\begin{abstract}
The studies were motivated by the interest the authors will be assistant social training in enhancing the ability Facilitation Programwith business groups. The purpose of this study to gain an overview of 1) The learning process is learning s ocial as sistant training KUBE, 2) to improve the facilitation of s ocial companion KUBEand 3 ) factors affecting the implementation of the assistant social training KUBE in BBPPKS. The method used in this penalizing is a descriptive and qualitative approach to the subject of research managers, trainers, social as sis tant training graduates and members of KUBE. Data collection techniques using observation, interviews, documentary studies and triangulation of data in BBPPKS Regional II Bandung. From the results obtained the following conclusions: (1) The learning process KUBE analyzed assistant social training of procedures, approaches, methods, techniques and learning media. The learning process has been tailored to the training needs; (2) to improve the facilitation of social as sistant business groups were analyzed from the as pect of knowledge, attitudes, and skills. their improvement felt by KUBE companion who had been trained in BBPPKS social assistant and a member of KUBE; (3) The supporting factors including planning, budgeting, government programs, infras tructure, the use of media and methods varied, the competence of lecturers, creating relationships of various parties, able to tighten the friendship and communication between companion KUBE program in solving the problems that exist.
\end{abstract}

Keywords : Training, Social As sistants, Ability Facilitation, Business Group .

\section{A. PENDAHULUAN}

Latar belakang dari permasalahan penelitian ini yaitu berasal dari is u kemiskinan Kemiskinan menjadi salah satu masalah besar yang menjadi perbincangan di masyarakat luas. Kemiskinan menjadi salah satu aspek yang terdapat pada MDGs (Millineum Development Gold) yang menjadi salah satu tolak ukur pembangunan negara. Menurut BPS dan Depsos dalam Suharto (2009, hlm.134) bahwa Kemiskinan merupakan sebuah kondisi yang berada di bawah garis nilai standar kebutuhan minimum, baik untuk makanan dan non makanan, yang disebut garis kemiskinan (poverty line) atau batasan kemiskinan (poverty threshold). Garis kemiskina adalah sejumlah rupiah yang diperlukan oleh setiap individu untuk dapat membayar kebutuhan makanan setara 2100/kg perhari dan kebutuhan non makanan yang terdiri dari perumahan, pakaian, kesehatan, pendidikan, transportasi,serta aneka barang dan jasa lainya.

Indonesia merupakan salah satu negara berkembang yang memiliki jumlah 
237.641.326 Jiwa. Jawa barat merupakan salah satu wilayah di Indonesia yang memiliki jumlah penduduk yang cukup banyak, menurut Data SIAK Provinsi Jawa Barat didiami penduduk sebanyak 46.497.175 Juta Jiwa. Penduduk ini tersebar di 26 Kabupaten/Kota, 625 Kecamatan dan 5.899 Desa/Kelurahan. Data BPS menerangkan terdapat warga miskin dengan jumlah 27727,78 jiwa/September 2014 dengan besaran $10,96 \%$ tersebar dari berbagai provinsi di indonesia (www.bps.go.id). Dari pemaparan diatas seyogyanya pemerintah dan masyarakat harus bekerja sama dalam menghapuskan atau mengurangi tingkat kemiskinan yang ada. Salah satu solusi dalam memecahkan masalah kemiskinan di indonesia, pemerintah melalui kementrian sosial RI memiliki program kelompok usaha bersama (KUBE) bagi fakir miskin yang bertujuan untuk meningkatkan usaha ekonomi produktif khusunya dalam peningkatan ekonomi.

Program kelompok usaha bersama berdasarkan pedoman pertumbuhan dan pengembangan kelompok usaha bersama (KUBE) Departemen Sosial RI Tahun 2010 Yaitu KUBE adalah kelompok warga atau keluarga binaan sosial yang telah dibina melalui proses program kegiatan kesejahteraan sosial untuk melaksanakan kegiatan kesejahteraan sosial dan usaha ekonomi dalam semangat kebersamaan sebagai sarana untuk meningkatkan taraf kesejahteraan. Keberhasilan dari kelompok usaha bersama di pengaruhi oleh kualitas tenaga kesejahteraan sosial masyarakat yaitu pendamping sosial yang menguasai pemahaman kesejahteraan sosial di masyarakat. Program penanganan kemiskinan, contohnya masyarakat miskin yang di bantu merupakan kelompok masyarakat yang tidak berdaya karena hambatan faktor internal maupun external. Pendamping sosial KUBE kemudian hadir untuk memecahkan masalah masyarakat.

Menurut Suharto (2009, hal.94) memaparkan "Pendampingan sosial dapat diartikan sebagai interaksi dinamis antara kelompok miskin dan pekerja sosial untuk secara bersama-sama menghadapi beragam tantangan seperti, merancang program perbaikan kehidupan ekonomi, mobilisasi sumberdaya setempat, memecahkan masalah sosial, menciptakan atau membuka akses bagi pemenuhan kebutuhan, menjalin kerja sama dengan pihak lainya yang sesuai dengan konteks pemberdayaan masyarakat. Pendampingan sosial KUBE merupakan salah satu strategi dalam menentukan keberhasilan program pemberdayaan ekonomi masyarakat miskin. Dalam program penanganan masalah kemiskinan, masyarakat yang mendapatkan bantuan seringkali merupakan kelompok yang tidak mampu. Pendamping sosial kemudian hadir sebagai agen perubah yang terlibat membantu Dalam rangka mengoptimalka n kelompok usaha bersama (KUBE) bagi masyarakat, pemerintah memberikan kebijakan terhadap balai besar pendidikan dan pelatihan kesejahteraan sosial untuk meningkatkan kemampuan pendamping kelompok usaha bersama melalui dunia pendidikan sehingga dapat menjadi sumber daya manusia yang berkualitas.

Balai besar pendidikan dan pelatihan kesejahteraan sosial (BBPPKS) Regional II Bandung menyelenggarakan kegiatan pelatihan bagi pendamping sosial KUBE untuk meningkatkan kompetensi yang dimiliki tenaga kerja sosial masyarakat agar (TKSM) dapat melaksanakan tugas dan fungsinya di masyarakat. Dalam undangundang Nomor 20 tahun 2003 pasal 26 ayat 5 memaparkan bahwa Lembaga kursus atau pelatihan adalah satuan pendidikan non 
formal yang berfungsi menyelenggarakan kursus atau pelatihan bagi masyarakat yang memerlukan bekal pengetahuan, keterampilan, kecakapan hidup, sikap untuk mengembangkan diri, mengembangkan profesi, bekerja, usaha mandiri, dan melanjutkan pendidikan pada jenjang yang lebih tinggi.

Menurut kamus umum bahasa indonesia pelatihan merupakan pelajaran untuk memperoleh suatu keterampilan, sedangkan menurut Flippo (dalam kartika, 2011, hlm.8) memaparkan "Pelatihan merupakan suatu usaha pengetahuan dan keterampilan agar karyawan dapat mengerjakan suatu pekerjaan tertentu. Dari Pemaparan di atas mendefinisikan pelatihan merupakan rangkaian kegiatan yang dilakukan untuk memperoleh atau meningkatkan kompetensi yang dimiliki”. Kondisi yang ditemukan pada tempat penelitian yaitu Balai BesarPendidikan dan Pelatihan Kesejahteraan Sosial (BBPPKS) Regional II Bandung disana terdapat beberapa kegiatan pelatihan. pelatihan yang di laksanakan bagi tenaga kerja sosial pemerintah dan tenaga kerja sosial masyarakat. Peneliti memilih pelatihan pendamping KUBE bagi tenaga kesejahteraan masyarakat sebagai penelitian karena program kelompok usaha bersama menjadi salah satu upaya pemerintah dalam menentaskan masalah kemiskinan khusunya di Indonesia.

Pelatihan pendamping sosial KUBE yang dilaksanakan oleh Balai Besar Pendidikan dan Pelatihan Kesejahteraan Sosial (BBPPKS) Bandung merupakan pelatihan yang bertujuan untuk meningkatkan kemampuan yang dimiliki oleh tenaga kerja sosial masyarakat, sehingga dapat melaksanakan tugas dan fungsinya secara maksimal di masyarakat. Pelatihan ini dilaksanakan pada tahun 2015 sebagai pelatihan reguler yaitu pelatihan yang dilaksanakan berdasarkan kebutuhan dengan jumlah peserta 39 orang berasaldari provinsi wilayah kerja BBPPKS Regional Bandung yaitu Provinsi Jawa Barat, Provinsi Kalimantan Barat, Provinsi Kepulauan Bangka Belitung, Provinsi Lampung, Provinsi DKI Jakarta dan Provinsi Banten. Terdapat peningkatan kemampuan peserta pelatihan pendamping KUBE sebesar 22,99\%. Sebelum pelatihan tingkat kemampuan peserta adalah $72,01 \%$ dan sesudah Pelatihan kemampuan peserta meningkat menjadi 98,65 \%. Hal ini didapatkan setelah kegiatan pembelajaran dan evaluasi pelatihan KUBE di BBPPKS Regional II Bandung.

Adapun tujuan dari penelitian ini yaitu: 1) Mengetahui proses pembelajaran pelatihan pendamping sosial kelompok usaha bersama di BBPPKS, 2) Mendeskripsikan peningkatan kemampuan fasilitasi pendamping sosial kelompok usaha bersama, 3) Mendeskripsikan faktor yang mempengaruhi dalam pelaksanaan pelatihan pendampingan sosial kelompok usaha bersama di BBPPKS.

\section{B. KAJIAN LITERATUR}

Menurut Edwin B flippo (dalam Kamil, 2012, hlm. 3) memaparkan 'Training atau pelatihan adalah tindakan dalam meningkatkan pengetahuan dan keterampilan seorang pegawai untuk melaksanakan pekerjaan tertentu'. Lebih luas menurut undang-undang Nomor 20 tahun 2003 pasal 26 ayat 5 menyebutkan bahwa Kursus atau pelatihan adalah satuan pendidikan non formal yang berfungsi menyelenggarakan kursus atau pelatihan bagi masyarakat yang memerlukan bekal pengetahuan, keterampilan, kecakapan hidup, sikap untuk mengembangkan diri, mengembangkan profesi, bekerja, usaha mandiri, dan melanjutkan pendidikan pada jenjang yang lebih tinggi. Dari Pemaparan 
di atas mendefinisikan pelatihan merupakan rangkaian kegiatan yang dilakukan untuk memperoleh atau meningkatkan kompetensi yang dimiliki baik aspek kognitif, afektif dan psikomotor. Menurut Tim deliveri (dalam Mardikanto, 2013, hlm. 76) memaparkan pemberdayaan masyarakat " sebagai suatu proses yang bertitik tolak untuk memandirikan masyarakat agar dapat meningkatkan taraf hidupnya sendiri dengan menggunakan dan mengakses sumberdaya setempat sebaik mungkin". Program kelompok usaha bersama berdasarkan pedoman pertumbuhan dan pengembangan kelompok usaha bersama (KUBE) Departemen Sosial RI Tahun 2010 memaparkan "KUBE adalah kelompok warga atau keluarga binaan sosial yang telah dibina melalui proses program kegiatan kesejahteraan sosial untuk melaksanakan kegiatan kesejahteraan sosial dan usaha ekonomi dalam semangat kebersamaan sebagai sarana untuk meningkatkan taraf kesejahteraan". Dari pemaparan diatas kehadiran kelompok usaha bersama (KUBE) merupakan media untuk meningkatkan motivasi masyarakat miskin untuk lebih maju secara ekonomi dan sosial, meningkatkan interaksi dan kerjasama dalam kelompoknya, memaksimalkan potensi dan sumber sosial ekonomi lokal. hasil belajar merupakan kemampuan-kemampuan yang dimiliki oleh peserta didik setelah mengikuti proses pembelajaranya.

Menurut Horward kingsley (dalam Nana, 2011, hlm. 22) membagi tiga macam hasil belajar yakni pengetahuan dan pengertian, sikap dan cita-cita, dan keterampilan dan kebiasaan. Hal ini diperkuat dengan pendapat Bloom yang secara garis besar membagi hasil ranah belajar menjadi tiga aspek yaitu, aspek kognitif, afektif dan psikomotor. Ranah pengetahuan atau kognitif terdapat enam jenjang untuk berfikir, Lebih lanjut menurut Bloom Nana (2011. hlm.23-28) “ Terdapat enam tingkatan proses berfikir manusia dari jenjanng terendah hingga jenjang yang tinggi yaitu pengetahuan, pemahaman, penerapan, analisis, sintetis, hingga evaluasi”. Dalam Nana (2011, hlm. 30 ) memaparkan " ada beberapa jenis kategori ranah sikap dan nilai sebagai hasil belajar dimulai dari reciving atau attending, responding atau jawaban, valuing atau penilaian, organisasi dan karakteristik atau internalisasi nilai". Lebih lanjut dalam Nana (2011. hlm. 30-31) “ terdapat enam tingkatan keterampilan yaitu gerak refleks, keterampilan gerak-gerak dasar, kemampuan perseptual, kemampuan bidang fisik, gerak-gerakan skill, kemampuan dalam berkomunikasi”.

Pengertian "Fasilitasi" secara harfiah merujuk pada "Upaya dalam memberikan kemudahan" kepada siapa saja agar mampu mengerahkan kemampuan dan sumber daya dengan tujuan untuk memecahkan masalah yang dihadapinya (Sumpeno, 2009, hlm. 2). Sedangkan menurut Kartika (2011, hlm. 104) memaparkan "fasilitasi dapat diartikan sebagai "melayani" dan memperlancar aktivitas untuk mencapai tujuan tertentu, orang yang mempermudah dapat disebut sebagai fasilitator". Fasilitator Merupakan peran yang berkaitan dengan pemberian motivasi, kesempatan, dan dukungan bagi masyarakat. Beberapa tugas yang berkaitan dengan peran ini antara lain menjadi model, melakukan mediasi dan negosiasi, memberi dukungan, membangun konsensus bersama, serta melakukan pengorganisasian dan pemanfaatan sumber. (Suharto, 2013, hlm.95)

Lebih lanjut menurut Sandor $P$. Schuman dan Haryono (dalam Saepudin 2013, hlm. 78) memaparkan bahwa kemampuan fasilitator yang baik adalah berkomunikasi yang baik dalam artian fasilitator mampu mendengarkan keluh kesah dari anggotanya selanjutnya mampu menyimpulkan dan menggali keterangan lebih lanjut. fasilitator dapat mengormati dan menghargai perasaan dari setiap anggota, memiliki pengetahuan yang berkaitan dengan fokus kegiatan yang bersangkutan, dan memiliki sifat permisif 
(keterbukaan) artinya fasilitator menerima pendapat atau pandangan dari masyarakat walaupun pandangan tersebut berbeda dengan padangannya.

\section{METODE PENELITIAN}

Pendekatan penelitian ini menggunakan pendekatan kualitatif Menurut Syaodih (2011, hlm. 60) memaparkan " Penelitian kualitatif adalah suatu penelitian yang ditunjukan untuk mendeskripsikan dan menganalisis fenomena, peristiwa, aktivitas sosial, sikap, kepercayaan, presepsi, pemikiran orang secara individual maupun kelompok". Penelitian ini memiliki tujuan untuk menggambarkan fenomena-fenomena yang ada, yang berlangsung pada saat ini atau saat lampau.

Penelitian ini menggunakan metode penelitian deskriptif, penelitian ini merupakan penelitian dasar. Menurut Syaodih (2011, hlm. 72) memaparkan "Metode deskriptif ditujukan untuk mendeskripsikan dan menggambarkan fenomena-fenomena yang ada baik fenomena yang bersifat alamiah maupun buatan manusia". Penelitian ini mengkaji dalam bentuk karakteristik, aktivitas, perubahan, hubungan, kesamaan dan perbedaan dengan fenomena lainya. Pengumpulan data kualitatif bersifat interaktif yang memiliki langkah-langkah yang saling berkaitan.

Penelitian ini akan mendeskripsikan, menjelaskan, dan memaparkan secara lebih dalam mengenai pelatihan pendamping sosial dalam meningkatkan kemampuan fasilitasi program kelompok usaha bersama. pelatihan ini dilaksanakan di BBPPKS Regional II Bandung yang bertempat di jalan Panorama no. 1 Lembang. Subjek Penelitian ini ditentukan secara purposive,' 'artinya subjek penelitian sebagai sumber data dipilih dengan pertimbangan tertentu. Sugiyono (2014, hlm 15). Subjek dalam penelitian ini adalah seluruh komponen dari kegiatan pelatihan yaitu pengelola, widyaiswara, lulusan pelatihan dan anggota KUBE. Teknik pengumpulan data merupakan cara-cara atau langkah-langkah yang ditempuh untuk menghimpun data dalam usaha pemecahan permasalahan penelitian. Teknik yang digunakan oleh peneliti yaitu : observasi, wawancara, dan studi dokumentasi. Dalam hal ini, wawancara dilakukan kepada beberapa responden, yaitu: (1) Pengelola BBPPKS yang bernama Ari setiadi, S.Sos,(2) Dr. Endah Triati, MSW sebagai widyaiswara, (3) Nani sumarni dan Abin Rosadi sebagai lulusan pelatihan dan (4) nengsih dan anih sebagai anggota KUBE.

Data yang terkumpul dari lapangan selanjutnya dianalisis oleh peneliti dengan tujuan akan mengambil hal-hal yang penting dalam menjawab pertanyaan yang ada dalam rumusan masalah. Analisis data dalam penelitian kualitatif dilakukan sejak sebelum memasuki lapangan, selama di lapangan dan setelah selesai di lapangan. Lebih lanjut Nasution (dalam sugiyono, 2014, hlm.336) memaparkan bahwa Analisis telah mulai sejak merumuskan dan menjelaskan masalah, sebelum terjun ke lapangan, dan berlangsung terus menerus sampai penulisan hasil penelitian. Analisis data menjadi pegangan bagi penelitian selanjutnya sampai jika mungkin, teori yang graunded".

Analisis sebelum di lapangan di lakukan terhadap data hasil studi pendahuluan, atau data sekunder yang digunakan untuk menentukan fokus penelitian. Sedangkan, Aktivitas selama di lapangan menggunakan mpdel miles dan huberman (dalam sugiyono, 2014, hal.337) mengemukakan "Aktivitas dalam analisi data kualitatif dilakukan secara interaktif dan berlangsung secara terus menerus sampai tuntas, sehingga datanya sudah jenuh" dalam analisis data diantaranya (Sugiyono, 2014, hlm. 337) data reduction (reduksi data), data display (penyajian data) dan conclusiondrawing/verification (tahap kesimpulan).

\section{HASIL PENELITIAN DAN PEMBAHASAN}


Interpretasi hasil penelitian mengacu kepada tujuan penelitian yaitu untuk mendeskripsikan tentang: (1) Proses pembelajaran pelatihan pendamping sosial kelompok usaha bersama di BBPPKS, (2) Peningkatan kemampuan fasilitasi pendamping sosial kelompok usaha bersama, (3) Faktor yang mempengaruhi dalam pelaksanaan pelatihan pendampingan sosial kelompok usaha bersama di BBPPKS.

\section{Proses Pembelajaran Pelatihan Pendamping Sosial Kelompok Usaha Bersama Di BBPPKS}

Proses pembelajaran dapat dilihat dari aspek prosedur, pendekatan, metode dan media pembelajaran yang digunakan dalam pelatihan pendamping sosial KUBE. prosedur berkaitan dengan identifikasi kebutuhan peserta, tujuan pelatihan, dan sasaran.

Identifikasi kebutuhan peserta pelatihan menggunakan metode langsung dan tidak langsung. Identifikasi kebutuhan peserta pelatihan bertujuan untuk memahami dan mengenal karakterisitik peserta pelatihan pendamping sosial KUBE. Secara langsung pengelola dan widyaiswara melakukan interaksi seperti tanya jawab, perkenalan dan lain-lain dengn peserta pelatihan, untuk metode tidak langsung pengelola dan widyaiswara mengidentifikasi kebutuhan peserta dilihat dari profil, surat tugas, SPPD, bukti perjalanan dan dokumen administrasi lainya.

Terdapat tujuan khusus dan tujuan umum dari penyelengaraan pelatihan pendamping sosial KUBE. Tujuan umumnya untuk meningkatkan kemampuan dari aspek pengetahuan, sikap dan keterampilan peserta pelatihan. Sedangkan tujuan khususnya adalah Mengembangkan pengetahuan, kemampuan dan keterampilan Pendamping dalam rangka menggali dan memecahkan masalah, memperkuat dukungan, mendayagunakan berbagai sumber dan potensi dalam pemenuhan kebutuhan hidup fakir miskin dalam wadah KUBE. Mengembangkan keahlian pengelolaan bidang usaha kesejahteraan sosial dan usaha ekonomi produktif melalui KUBE. Dan Mengembangkan sikap dan karakter Pendamping sehingga memiliki kemauan kerjasama dalam neningkatkan akses anggota KUBE terhadap pelayanan sosial dasar, lapangan kerja, dan fasilitas pelayanan publik lainnya.

Sasaran Pelatihan pendamping sosial KUBE terdiri dari para pendamping KUBE Kecamatan dan pendamping KUBE Desa, dengan persyaratan sebagai berikut, pendamping Berasal bukan dari Pegawai Negeri Sipil pada Dinas atau Instansi Sosial Kabupaten/Provinsi, Calon peserta adalah petugas yang dipanggil oleh Balai Besar sesuai data dari Kementerian Sosial Cq. Dit PKPP sebagai hasil dari proses rekrutmen dan seleksi, Diajukan dari Dinas/Instansi Sosial Kabupaten/provinsi Instansi Sosial Provinsi, Sehat jasmani dan rohani, dan Bersedia mengikuti Bimbingan Pemantapan Pendamping KUBE.

Pendekatan yang digunakan dalam penyelenggaraan pelatihan bagi pendamping sosial KUBE adalah model pendekatan orang dewasa (andragogik). Penggunaan pendekatan orang dewasa ini di latarbelakangi oleh konsep hidup, pengalaman tujuan, kesiapan belajar hingga orientasi belajar peserta pelatihan yang berbeda-beda satu sama lainya. Menurut Kamil (2012, hlm. 161) memaparkan “...Dalam pelaksanaan pelatihan pendekatan yang digunakan adalah model pendidikan orang dewasa, yakni dengan memanfaatkan pengalaman-pengalaman peserta pelatihan sebagai sumber belajar untuk terlibat dalam perencanaan, pelaksanaan hingga penilaian". Dalam berjalanya proses pembelajaran pelatihan menggunakan pendekatan andragogi yang di artikan sebagai ilmu dan seni membantu orang dewasa. Pendidikan orang dewasa (Andragogy).

Penggunaan metode dan teknik yang tepat akan menciptakan pelatihan yang 
efektif dan efesien. Hal ini sejalan dengan Kamil (2012, hlm. 11-13) Terdapat berbagai metode-metode pelatihan yang ada, pelaksanaan program pelatihan harus menggunakan metode-metode yang sesuai dengan kondisi pelatihan. Hal tersebut dilakukan untuk menciptakan kondisi yang baik. Metode dan teknik pembelajaran yang digunakan dalam pelatihan pendamping sosial KUBE di BBPPKS Regional II Bandung antara lain adalah menggunakan metode ceramah dan tanya jawab, diskusi kelompok dan pleno, permainan peran dan curah pendapat.

Media pembelajaran yang digunakan dalam pelatihan pendamping sosial KUBE diantaranya menggunakan media pembelajaran bervariasi dimulai LCD, OHP, papan tulis, video, Laptop, Kertas buram, pedoman penyelenggaraan pelatihan, flip chart, spidol, karton dan lainya.

\section{Peningkatan Kemampuan Fasilitasi Pendamping Sosial Kelompok Usaha Bersama}

Peningkatan kemampuan fasilitasi pendamping sosial KUBE dilihat dari aspek pengetahuan, sikap dan keterampilan. Peningkatan kemampuan dalam aspek pengetahuan hasil penelitian memaparkan Pengetahuan yang di berikan mampu meningkatkan kemampuan pendamping KUBE dalam melakukan pendampingan terhadap anggota kelompok usaha bersama (KUBE). kemampuan fasilitasi yang di miliki oleh pendamping sosial yang mengikuti pelatihan bertambah, hal ini dilihat dari hasil Pre dan post test yang menyatakan adanya peningkatan kemampuan dari aspek pengetahuan pendamping sosial KUBE.

Hasil evaluasi Terdapat peningkatan kemampuan peserta pelatihan pendamping KUBE sebesar $22,99 \%$. Sebelum pelatihan tingkat kemampuan peserta adalah 72,01\% dan sesudah Pelatihan kemampuan peserta meningkat menjadi 98,65 \%. Hal ini didapatkan setelah kegiatan pembelajaran dan evaluasi pelatihan KUBE di BBPPKS
Regional II Bandung. Dengan kata lain pelatihan ini mampu meningkatkan kemampuan peserta pelatihan pendamping sosial khusunya dalam bidang penguasaan pengetahuan.

Peningkatan kemampuan dalam aspek sikap. Dari hasil penelitian bahwa pelatihan pendamping sosial KUBE yang diselenggarakan di BBPPKS Regional II Bandung memberikan efek positif bagi peningkatan kemampuan fasilitasi dalam aspek sikap. Peningkatan yang terjadi dilihat dari kemampuan pendamping KUBE dalam berkomunikasi, menghormati anggota KUBE dan masyarakat, dan keterbukaan (Permisif).

Sikap yang di miliki fasilitator yang baik adalah berkomunikasi yang baik dalam artian fasilitator mampu mendengarkan keluh kesah dari anggotanya selanjutnya mampu menyimpulkan dan menggali keterangan lebih lanjut. fasilitator dapat mengormati dan menghargai perasaan dari setiap anggota, memiliki pengetahuan yang berkaitan dengan fokus kegiatan yang bersangkutan, dan memiliki sifat permisif (keterbukaan) artinya fasilitator menerima pendapat atau pandangan dari masyarakat walaupun pandangan tersebut berbeda dengan padangannya.

Peningkatan kemampuan dalam aspek keterampilan. Pelatihan pendamping sosial KUBE memberikan efek positif terhadapa peningkatan kemampuan keterampilan yang dimiliki oleh pendamping dalam memfasilitasi kelompok usaha bersama (KUBE). keterampilan yang dimiliki oleh pendamping sosial yaitu, menjadi model, melakukan mediasi dan negosiasi, memberi dukungan, membangun konsensus bersama, serta melakukan pengorganisasian dan pemanfaatan sumber. Menjadi model artinya fasilitator yang baik tidak hanya menguasai materi saja, tetapi harus memberikan contoh penerapanya secara praktis. Menjadi mediasi dan negosiasi dal hal ini fasilitator berperan sebagai orang ketiga dalam menjebatani antar anggota kelompok penerima manfaat 
dan sistem lingkungan yang menghambat. Sedangkan negosiasi bertujuan untuk memfasilitasi dan membantu pihak-pihak yang bertikai untuk mencapai satu kesepakatan. Memberikan dukungan yang mengacu dalam mengaplikasikan keterampilan yang dapat memberikan perubahan yang sifatnya positif. Membangun konsensus bersama bertujuan untuk mengambil suatu keputusan atau kesepakatan yang disetujui secara bersamasama. Sedangkan melakukan pengorganisasian dan pemanfaatan sumber berkaitan dengan pengorganisasian kelompok-kelompok masyarakat perlu disertai dengan peningkatan kemampuan anggota kelompoknya membangun dan mempertahankan jaringannya sehingga mampu menyediakan dan mengembangkan pemanfaatan sumber yang ada.

Peneliti mendapatkan gambaran dari hasil penelitian bahwa keterampilan yang dimiliki oleh pendamping sosia dapat dilihat dari aspek model (Peran Pendamping KUBE ), mediasi dan negosiasi, melakukan konsensus bersama, dan pengorganisasian dan pemanfaatan sumber. Dari pemaparan diatas pendamping sosial KUBE harus mampu turun langsung dalam pendampingan KUBE mulai dari tahapan perencanaan, pelaksanaan dan evaluasi. Peran pendamping sosial dalam mediasi dan negosiasi berperan menjadi pihak ketiga.

\section{Faktor Yang Mempengaruhi Dalam Pelaksanaan Pelatihan Pendampingan Sosial Kelompok Us aha Bers ama Di BBPPKS}

Faktor yang mempengaruhi pelaksanaan pelatihan pendamping sosial KUBE dianalisis melalui faktor pendukung dan faktor penghambat. Faktor pendukung penyelenggaraan pelatihan ini dilatar belakangi oleh profesional pegawai BBPPKS Regional II Bandung, perencanaan matang yang sudah dirancang dari jauh sebelum penyelengaraan pelatihan dimulai. Anggaran yang sudah dirancangdan dirinci semaksimal mungkin oleh berbagai pihak terkait, perhatian tinggi dari pemerintah untuk pelaksanaan program pelatihan pendamping sosial di BBPPKS Regional II Bandung, sarana prasarana pendukung berjalanya pelatihan cukup lengkap, penggunaan media dan metode yang bervariatif akan mempermudah dalam meningkatkan kemampuan peserta pelatihan, sebelum pelatihan dilaksanakan widyaiswara mengikuti pelatihan bagi pelatih yang bertujuan untuk meningkatkan kompetensi widyaiswara. Peluang yang diciptakan pelatihan ini adalah pendamping sosial KUBE mampu menciptakan relasi baik pemerintah maupun swasta, pelatihan ini mampu mempererat tali silaturahim antar pendamping KUBE, dan pelatihan ini menjadi wadah untuk saling bertukar fikiran dalam memecahkan permasalahan program KUBE yang ada.

Faktor penghambat pelatihan ini adalah cuaca yang dingin tidak semua peserta mampu beradaptasi dengan cuaca yang dingin di wilayah lembang, kemampuan narasumber atau widyaiswara dalam menciptakan kondisi yang kondusif tidak semua sama, motivasi belajar peserta pelatihan tidak semua sama, kemampuan peserta berbeda-beda. Ancaman yang menjadi penghambat pelaksanaan pelatihan yaitu jika jumlah peserta tidak sesuai dengan quota yang sudah ditetapkan oleh pemerintah.

\section{E. SIMPULAN DAN REKOMENDASI}

Proses pembelajaran dapat dilihat dari aspek prosedur, pendekatan, metode dan media pembelajaran yang digunakan dalam pelatihan pendamping sosial KUBE. prosedur berkaitan dengan identifikasi kebutuhan peserta, tujuan pelatihan, dan sasaran.

Identifikasi kebutuhan peserta pelatihan menggunakan metode langsung dan tidak langsung. Identifikasi kebutuhan peserta pelatihan bertujuan untuk memahami dan mengenal karakterisitik peserta pelatihan pendamping sosial 
KUBE. Terdapat tujuan khusus dan tujuan umum dari penyelengaraan pelatihan pendamping sosial KUBE. Tujuan umumnya untuk meningkatkan kemampuan dari aspek pengetahuan, sikap dan keterampilan peserta pelatihan. Sedangkan tujuan khususnya adalah Mengembangkan pengetahuan, kemampuan dan keterampilan Pendamping dalam rangka menggali dan memecahkan masalah, memperkuat dukungan, mendayagunakan berbagai sumber dan potensi dalam pemenuhan kebutuhan hidup fakir miskin dalam wadah KUBE. Mengembangkan keahlian pengelolaan bidang usaha kesejahteraan sosial dan usaha ekonomi produktif melalui KUBE. Dan Mengembangkan sikap dan karakter Pendamping sehingga memiliki kemauan kerjasama dalam neningkatkan akses anggota KUBE terhadap pelayanan sosial dasar, lapangan kerja, dan fasilitas pelayanan publik lainnya.

Sasaran Pelatihan pendamping sosial KUBE terdiri dari para pendamping KUBE Kecamatan dan pendamping KUBE Desa, dengan persyaratan sebagai berikut, pendamping Berasal bukan dari Pegawai Negeri Sipil pada Dinas atau Instansi Sosial Kabupaten/Provinsi, Calon peserta adalah petugas yang dipanggil oleh Balai Besar sesuai data dari Kementerian Sosial Cq. Dit PKPP sebagai hasil dari proses rekrutmen dan seleksi, Diajukan dari Dinas/Instansi Sosial Kabupaten/provinsi Instansi Sosial Provinsi, Sehat jasmani dan rohani, dan Bersedia mengikuti Bimbingan Pemantapan Pendamping KUBE.

Pendekatan yang digunakan dalam penyelenggaraan pelatihan bagi pendamping sosial KUBE adalah model pendekatan orang dewasa (andragogik). Penggunaan pendekatan orang dewasa ini di latarbelakangi oleh konsep hidup, pengalaman tujuan, kesiapan belajar hingga orientasi belajar peserta pelatihan yang berbeda-beda satu sama lainya.

Metode dan teknik pembelajaran yang digunakan dalam pelatihan pendamping sosial KUBE di BBPPKS Regional II
Bandung antara lain adalah menggunakan metode ceramah dan tanya jawab, diskusi kelompok dan pleno, permainan peran dan curah pendapat.

Media pembelajaran yang digunakan dalam pelatihan pendamping sosial KUBE diantaranya menggunakan media pembelajaran bervariasi dimulai LCD, OHP, papan tulis, video, Laptop, Kertas buram, pedoman penyelenggaraan pelatihan, flip chart, spidol, karton dan lainya.

Peningkatan dalam aspek pengetahuan. Pengetahuan yang di berikan mampu meningkatkan kemampuan pendamping KUBE dalam melakukan pendampingan terhadap anggota kelompok usaha bersama (KUBE). Hasil evaluasi Terdapat peningkatan kemampuan peserta pelatihan pendamping KUBE sebesar $22,99 \%$. Sebelum pelatihan tingkat kemampuan peserta adalah $72,01 \%$ dan sesudah Pelatihan kemampuan peserta meningkat menjadi 98,65 \%. Hal ini didapatkan setelah kegiatan pembelajaran dan evaluasi pelatihan KUBE di BBPPKS Regional II Bandung. Dengan kata lain pelatihan ini mampu meningkatkan kemampuan peserta pelatihan pendamping sosial khusunya dalam bidang penguasaan pengetahuan.

Peningkatan kemampuan dalam aspek sikap. Pelatihan pendamping sosial KUBE memberikan efek positif terhadap sikap yang dimiliki pendamping dalam memfasilitasi program usaha bersama (KUBE). Sikap yang di miliki fasilitator yang baik adalah berkomunikasi yang baik dalam artian fasilitator mampu mendengarkan keluh kesah dari anggotanya selanjutnya mampu menyimpulkan dan menggali keterangan lebih lanjut. fasilitator dapat mengormati dan menghargai perasaan dari setiap anggota, memiliki pengetahuan yang berkaitan dengan fokus kegiatan yang bersangkutan, dan memiliki sifat permisif (keterbukaan) artinya fasilitator menerima pendapat atau pandangan dari masyarakat walaupun 
pandangan tersebut berbeda dengan padangannya.

Peningkatan kemampuan dalam aspek keterampilan. Pelatihan pendamping sosial KUBE memberikan efek positi terhadapa peningkatan kemampuan keterampilan yang dimiliki oleh pendamping dalam memfasilitasi kelompok usaha bersama (KUBE). keterampilan yang dimiliki oleh pendamping sosial yaitu, menjadi model, melakukan mediasi dan negosiasi, memberi dukungan, membangun konsensus bersama, serta melakukan pengorganisasian dan pemanfaatan sumber. Menjadi model artinya fasilitator yang baik tidak hanya menguasai materi saja, tetapi harus memberikan contoh penerapanya secara praktis. Menjadi mediasi dan negosiasi dal hal ini fasilitator berperan sebagai orang ketiga dalam menjebatani antar anggota kelompok penerima manfaat dan sistem lingkungan yang menghambat. Sedangkan negosiasi bertujuan untuk memfasilitasi dan membantu pihak-pihak yang bertikai untuk mencapai satu kesepakatan. Memberikan dukungan yang mengacu dalam mengaplikasikan keterampilan yang dapat memberikan perubahan yang sifatnya positif. Membangun konsensus bersama bertujuan untuk mengambil suatu keputusan atau kesepakatan yang disetujui secara bersamasama. Sedangkan melakukan pengorganisasian dan pemanfaatan sumber berkaitan dengan pengorganisasian kelompok-kelompok masyarakat perlu disertai dengan peningkatan kemampuan anggota kelompoknya membangun dan mempertahankan jaringannya sehingga mampu menyediakan dan mengembangkan pemanfaatan sumber yang ada.

Saran yang dapat diberikan atas penelitian Setelah peneliti memaparkan hasil penelitian yang mengenai pelatihan pendamping sosial dalam meningkatkan kemampuasn fasilitasi kelompok usaha bersama (KUBE) yang diselenggarakan di BBPPKS Regaional II Bandung, maka berikut diungkapkan beberapa saran yang peneliti berikan untuk berbagai pihak yang terkait dalam pelatihan pendamping sosial KUBE.

Pengelola lebih meningkatkan kerjasama dan koordinasi dengan berbagai pihak, baik dengan widyaiswara, lulusan dan pihak pendukung lainya. Pengelola lebih memaksimalkan sarana dan prasarana pendukung yang ada di BBPPKS Regional II Bandung. Pengelola memberikan fasilitasi untuk membentuk suatu kelompok atau forum diskusi bagi lulusan-lulusan pelatihan pendamping sosial KUBE. Pembentukan forum diskusi bagi lulusan bertujuan untuk menjadi wadah komunika si antar pendamping KUBE yang tersebar di berbagai wilayah. Penyelenggaraan pelatihan pendamping sosial KUBE dapat dilaksanakan secara berkelanjutan dan berkesinambungan.

Widyaiswara lebih meningkatkan kerjasama dan koordinasi dengan berbagai pihak terkait dalam penyelenggaraan pelatihan bagi pendamping sosial KUBE. Widyaiswara lebih mengetahui dan memahami karakteristik peserta pelatihan serta mampu menciptakan suasana belajar yang kondusif dalam pelatihan pendamping sosial KUBE.

Lulusan pelatihan dapat menerapkan atau mengimplementasikan kemampuan dalam fasilitasi baik dari segi pengetahuan, sikap hingga keterampilan yang didapatkan dalam kegiatan pelatihan pendamping sosial KUBE yang diselenggarakan di BBPPKS Regional II Bandung, hal ini bertujuan agar lulusan mampu memberikan pendampingan program kelompok usaha bersama dengan semaksimal mungkin. Meningkatkan kerjasama atau koordinasi antar pendamping sosial KUBE yang tersebar di berbagai wilayah.

\section{F. REFERENSI}

Kartika, Ika. (2011). Mengelola Pelatihan Partisipatif. Bandung: Alfabeta

Kamil, Mustofa. (2012). Model Pendidikan Dan Pelatihan. Bandung : Alfabeta

Koentrajaningrat. (1994). Metode-Metode Penelitian Masyarakat. Jakarta : PT. Gramedia Pustaka Utama . 
Mardikanto, Totok. (2013). Pemberdayaan Masyarakat. Bandung : Alfabeta

Marzuki,Saleh. (2010). Pendidikan Nonformal. Bandung : PT Remaja Rosdakarya.

Pedoman Karya Tulis Ilmiah Universitas Pendidikan Indonesia (2014, hlm. 20) mengemukakan sistematika penulisan karya tulis.

Saepudin, Asep (2013). Pengembangan Model Fasilitasi Belajar Dalam Memberdayakan Masyarakat Pelaku Usaha Kecil (Studi pada Sentra Usaha Kerajinan Cibeusi di Kabupaten Sumedang). Bandung : PPS UPI

Sudjana, Djudju (2007). Sistem Dan Manajemen Pelatihan. Bandung : Falah

Sudjana, Djudju (2010). Pendidikan Nonformal Wawasan, Sejarah, Perkembangan, Filsafat \&Teori Pendukung, Serta Asas. Bandung: Falah.

Nana, Sudjana. (2011). Penilaian Hasil Proses Belajar Mengajar. (Cet. XV). Bandung: PT. Ramaja Rosdakarya

Sugiyono, (2014). Memahami Penelitian Kualitatif. Bandung: Alfabeta

Suharto, Edi. (2009). Membangun Masyarakat Memberdayakan Rakyat. Bandung : Reflika Aditama

Sumpeno, Wahyudi. (2009). Menjadi Fasilitator Genius. Yogyakarta : Pustaka Belajar

Suprijianto, (2005). Pendidikan Orang Dewasa. Jakarta: Bumi Aksara.

Syaodih, Nana. (2011). Metode Penelitian Pendidikan. Bandung: PT Remaja Rosdakarya.

Undang-undang dan Kebijakan :

Undang-undang Republik Indonesia No. 6 Tahun 1974 tentang kesejahteraan sosial.

Undang-Undang Tentang Pendidikan Nomor 20 Tahun 2003 Tentang Sistem Pendidikan Nasional.

Keputusan Mentri sosial Republik Indonesia N0 53/HUK/ 2013 tanggal 23 Juli 2003 tentang organisasi, tata kerja, tugas dan fungsi BBPPKS.
Undang-Undang No. 40 Tahun 2004 Tentang Jaminan Sosial Nasional.

Undang-undang No. 16 Tahun 2066 tentang Ragam Fasilitator.

Undang-Undang No. 11 Tahun 2009 Tentang Kesejahteraan Sosial.

Perpres No. 15 Tahun 2010 Tentang Percepatan Penanggulangan Kemiskinan.

Merujuk Pada Sistem Jaminan

Sosial Nasional Berdasarkan UU No.40 Tahun 2004.

Inpres No. 3 Tahun 2010 Tentang Rencana Tindak Percepatan Pencapaian Sasaran Program Pro-Rakyat.

Depeartemen sosial (Depsos) Tahun 2010 tentang Program Kelompok Usaha Bersama (KUBE).

Undang-undang SPN Bab II Pasal 4 tentang tujuan pendidikan.

\section{Web online.}

Badan pusat statistik. (2014). Jumlah penduduk miskikn wilayah jawa barat. Tersedia : www.bps.go.id (23 Juli 2015).

Kamus bahasa indonesia. (2014). Pengertian Efektifitas. Tersedia : http:kbbi.web.id. (20 Juni 2015).

\section{Sumber lainya.}

Pedoman penyelenggaraan pelatihan pendamping sosial KUBE di BBPPKS Regional II Bandung.

Pedoman pertumbuhan dan pengembangan KUBE

Profil BBPPKS II Regional II Bandung.

Atas terlaksananya kegiatan penelitian dan tersusunnya naskah artikel yang dimuat pada jurnal teknodik ini, disampaikan ucapan terimakasih kepada: (1) Pimpinan dan staf BBPPKS Regional II Bandung, (2) Pimpinan Departemen Pendidikan Luar Sekolah UPI, (3) mahasiswa Departemen Pendidikan Luar Sekolah UPI, serta (4) pimpinan dan tim penyunting Jurnal Teknodik . 